Latvijas politiskajā diskursā atšķirīgo kultūras tradīciju un etniskās dažādības problemātika tika "izslēgta" (sal. "izslēgšanas procedūras" M. Fuko darbos), aizstājot to ar lingvistiskās identitātes instrumentalizāciju noteikto grupu interesēs. Atgriežoties pie eksperta skatījuma, alternatīva šai situācijai būtu atgriešanās politiskajā laukā per se, aktualizējot tam raksturīgās debates starp "labēji - kreisi - centriski - liberāli - radikālajām partijām un nevis starp "savējiem - svešajiem"”' (249. lpp.).

V. Volkova metodoloǵiski pētnieciskās simpātijas, kā šķiet, gandrīz pilnībā ir Jirgena Hābermāsa pusē. Apzinoties zināmu utopiskuma devu J. Hābermāsa teorijā par tikumiski regulējamo un uz konsensu vērsto komunikāciju starp dažādām sabiedriskajām grupām, monogrāfijas autors tomēr uzsver ideju par etnisko minoritāšu pašnoteikšanos sabiedrības privātajā un publiskajā jomā, saskatot tajā iespēju pārvarēt etniskās un nacionālās (pilsoniskās) identitātes vērtību pretnostatìjumu, līdz ar to arī liberālisma un multikulturālisma pretnostatījumu (262. lpp.). Aicinājums aktualizēt publiskajās diskusijās J. Hābermāsa teoriju, šķiet, vairāk ir attiecināms uz Hābermāsu - politiḳi. Taču metodologiiskajā jomā būtu svarīgi atcerēties Hābermāsu - filozofu un Hābermāsu - sociologu, kurš lielā mērā balstījās tieši uz "normatīvisma" (izmantojot V. Volkova pētījuma terminoloǵiju) tradīciju, uzsverot komunikatīvā procesa normatīvo racionalitāti (pragmatisko uzdevumu risināšana morāles normu ietvaros). Iespējams, viena no monogrāfijas autora iecerēm arī bija likt lasītājam pamanīt šīs atškirīibas starp pētniecisko refleksiju un sociālo praksi.

Grāmatu caurauž spriedze starp etniskās identitātes izpratnes dažādiem aspektiem starp šā sociālā fenomena konceptualizāciju zinātniskajā diskursā un šā fenomena fiksāciju kultūrantropoloǵiskajā "blīvajā aprakstā" (Kliforda Gīrca termins). Un tas noteikti intriǵē uzmanīgu lasītāju, kurš tomēr vēlas saprast, kas slēpjas aiz vairākiem nezināmajiem grāmatas nosaukumā. V. Volkova grāmata īstajā laikā problematizē vienu no sabiedrības saliedētības problēmas aspektiem un ir nozīmīgs ieguldījums etnisko minoritāšu identitātes pētījumos Latvijā.

\title{
PAR LATVIJAS TELEVĪZIJU PIRMS PIECIEM GADIEM
}

Sergejs Kruks, Dr. sc. inf., Rīgas Stradiņa universitātes profesors

Jāņa Juzefoviča grāmata ([2017] Broadcasting and National Imagination in PostCommunist Latvia: Defining the Nation, Definig Public Televison. Bristol, Chicago : Intellect), kas ir tapusi uz vina doktora disertācijas pamata, izaicina daudzas Latvijas valdības politikas pamatnostādnes pilsoniskās sabiedrības, sabiedrības integrācijas, nacionālās identitātes un mediju jomā. J. Juzefovičs ir pētījis latviski un krieviski runājošās televīzijas auditorijas skatīšanās paradumus, cenšoties skaidrot, kā elektroniskais medijs veido un uztur nācijas tēlu. Problēmas formulējums šķiet pamatots, paturot prātā to, cik svarīgu nozīmi piedēvē televīzijai Trešajā atmodā, kā arī Latvijā noturīgus uzskatus, ka tieši simbolu koplietošana (nevis kopīgās prakses) ir harmoniskas sabiedrības pamats. Visuresošā televīzija - un pirmkārt sabiedriskā - esot šo simbolu radītāja, izplatîtāja un uzturētāja.

Šì grāmata iet pretējā virzienā - pētnieks skatās nevis, ko simboli dara ar cilvēkiem, bet kā cilvēki uztver, izprot un lieto simbolus. Empīrisko bāzi veido 13 intervijas fokusgrupās (kopumā 80 dalībnieku) un etnogrāfiskie vērojumi piecās ğimenēs. Teorētiski pētnieks 
balstās lielākoties uz Birmingemas kultūrstudiju skolas pieeju. Tās priekšrocība ir orientēšanās uz kultūras nozīmi indivīdu dzīvē, un "kultūra" ir tā parole, ar kuru autors var pievienoties politiskajām diskusijām Latvijā. Bet vienlaikus kultūrstudijas atzīst viedokḷu plurālismu un neelites škirai piederošo cilvēku tiesības un spējas pašiem konstruēt simbolisko realitāti, iesaistoties dialogā ar politiskas un intelektuālās elites sacerēto pasaules redzējumu.

Skaidrojot TV skatīšanās paradumus un mediētā vēstījuma interpretācijas, J. Juzefovičs apgāž priekšstatu par pasīvu auditoriju un pasīviem pilsoņiem, kuri nespēj atbildīgi rīkoties tāpēc, ka nav interiorizējuši atbilstīgas rakstura īpašības, piem., tiesiskuma izpratni, piederības sajūtu valstij, izpratni par demokrātisko institūciju funkcionēšanu. Tas, kā skatītāji interpretē televīzijas ziņu un aktualitāšu raidījumus, l̦auj pētniekam secināt, ka izpratne un sajūta ir klātesoši. Pilsonisko aktivitāti kavē stingra nepatika pret valdošo eliti - tā piemīt gan latviski, gan krieviski runājošiem skatītājiem. Un, tā kā sabiedriskā LTV ir radījusi par sevi varas cilvēku interešu aizstāvošās valdības institūcijas tēlu (jebkurā gadījumā tāds pastāv un LTV arī tagad, piecus gadus pēc J. Juzefoviča jau 2012. gadā pabeigtā empīiskā pētījuma, ir jāsper būtiski soḷi šî tēla dekonstruēšanai), tad auditorija aiziet prom no šì medija, dodot priekšroku komerciālajiem. Krieviski runājošo respondentu aiziešanu no LTV veicina arī simboliskā izslēgšana no kopienas, kuras veidošana jeb imagination/ izdomāšana esot tieši sabiedriskās televīzijas funkcija. Taču LTV koncepcija paredz etniskās kultūrnācijas izdomāšanu un programmā skatītāji nelatvieši neredz parādām nedz sev līdzīgos, nedz savas intereses un viedokḷus. Valdības iecerētā simboliskās kopības radīšana un uzturēšana ar sabiedriskā medija vēstijjumu starpniecību ir pretrunā ar kolektīvās identitātes darbības mehānismu. Simbols nostiprina ikdienas praktisko pieredzi, taču LTV šādas nepastarpinātās, ar kameru tieši tvertās un nesimbolizētās identificēšanās iespējas nepiedāvā.

Analizējot latviešu un krievu auditorijas nosauktos aiziešanas no sabiedriskās televīzijas iemeslus, J. Juzefovičs izdara trīs būtiskus secinājumus, kas apgāž gan teorētiķu, gan politiķu spriedumus. Pirmkārt, negatīvā attieksme pret varas eliti nenozīmē, ka ir apātija pret valsti vai trūkst intereses par iekšpolitiku: respondenti informāciju meklē citos medijos un apspriež uzzināto. Otrkārt, aiziešana nenozīmē, ka skatītājs zaudētu piederības sajūtu nacionālajai kopienai: respondentu izklāstītās pozitīvās psihologiiskās asociācijas ar sabiedrību liecina, ka viņi domā par saikni ar citiem un tā viņiem ir svarīga. Treškārt, komerctelevīzijas skatīšanās nenozīmē atteikšanos no pilsona lomas, par ko parasti uztraucas mediju teorētikiki. J. Juzefovičs demonstrē, ka komerctelevīzija spēj sekmēt pilsoņa lomas īstenošanu. Pilsona un patērētāja loma nav stingri pretstatītas un konkurējošas, bet mijiedarbojas. Latvijas gadījumā tirgus turklāt ir īstenojis sociāli svarīgu funkciju, no kuras eksplicīti atteikusies sabiedriskā televīzija. Proti, tirgus logíikas virzìtās komerctelevīzijas palielina savu skatītāju loku, vairojot kultūras daudzveidības reprezentāciju programmās.

Ir radusies visai paradoksāla situācija: sabiedriskajam medijam pēc definīcijas jābūt pieejamam bez maksas visiem, tam raidījumos jāreprezentē visas sociālās grupas un jātematizē šo grupu publiskās dienaskārtības jautājumi, taču krieviski runājošie pilsoņi un nepilsoṇi neatpazīst tajā sevi un savu pieredzi. Tāpēc J. Juzefovičs skarbi secina, ka sabiedriskie mediji var gan vienot, gan škelt nāciju (138. lpp). Savukārt vienotāja funkciju faktiski īsteno pie auditorijas segmentācijas principiem pieradušie komerciālie mediji. Tieši komerctelevīziju programmās respondenti ir smēlušies tos simbolus, kas iezīmē nāciju.

Integrēšanu kopienā var veikt arī lokalizētā transnacionālā televīzija. Runa ir par Krievijas Pirmā kanāla lokālo versiju Pirmais Baltijas kanāls (PBK). PBK skatīšanās nenozīmē bēgšanu Krievijas dz̄ivē. Respondenti saglabā kritisku distanci iepretī Maskavas žurnālistu vēstījumiem, bet aktīvi iesaistās Rīgas žurnālistu veidotajā diskursā par nacionālajām aktualitātēm. Un tā nebūt neesot "paralēlā informācijas telpa". Pēc valodas auditoriju var daudzmaz sadalīt divās grupās, bet interese par valsts dzīvi abās grupās ir kopīga. Dienaskārtība latviešu un krievu valodā skanošajās ziņās lielākoties ir tā pati, atškiriras to tematu rāmējumi, kuri jau šķir kopienas. Tāpēc sabiedriskajam (jo īpaši) medijam nācija būtu simboliski jākonstruē ap vienojošiem tematiem, kritiski interpretējot šķirošos. 
Politiskajā un diemžēè arī teorētiskajā diskursā latviešu valodā ir ierasts runāt par "vienotību": vienotā informācijas telpa, vienotā vēstures izpratne. Televīzijas lietošanas paradumu analīze liecina, ka nav vienotas publiskās sfēras, tāpat kā nav viena neproblemātiski definēta nacionālā "mēs". Latvijā faktiski pastāvošais plurālisms, kuru turklāt nenosaka piederība pie valodas un kultūras kopienas, ir pretrunā ar sabiedriskā medija kā visaptverošas publiskās sfēras koncepciju. Un - uzsver J. Juzefovičs plurālisms nenozīmē solidaritātes mazināšanos. Politikas veidotājiem būtu jāapzinās, ka starp medijiem latviešu un krievu valodā ir vairāki saskarsmes punkti, kas nel̦auj runāt par "paralēlajām informācijas telpām”. Tāpēc publiskā komunikācija var notikt (un tā jau notiek) arī pāri atsevišksiem medijiem un valodām.

Lielu uzmanību J. Juzefovičs pievērš populārajai kultūrai: Eirovīzijas konkursa un sporta spẹ̣̄u translācijām, Jaungada vakara programmām. Arī citi pētnieki Latvijā empīiski parādījuši šo pasākumu integrējošo funkciju. J. Juzefoviča sarunas ar respondentiem lieku reizi apliecina televīzijas potenciālu radīt kopības sajūtu. Pētnieks gan brīdina: nav obligāti, ka šī sajūta radītu nacionālo "mēs", kas būtu pieņemams visiem nācijas locekḷiem. Tomēr iedomātās kopienas teorētiķi nemaz neapgalvo, ka harmoniska vienotība būtu tās obligātais rezultāts.

Grāmatā autors neskar jautājumu par praksēm, kas ir uz J. Hābermāsa publiskās sfēras konceptu balstītās sabiedriskās televīzijas uzmanības centrā. Proti, publiskā sfēra ir vieta, kur indivīdi var spriest par savām privātajām interesēm kā pilsoņi, lai meklētu saskaņu ar līdzpilsoniem un ietekmētu lēmējvaras darbu. Respondentu apgalvojumi, ka vini neatpazīst sevi sabiedriskās televīzijas raidījumos, faktiski varētu liecināt par šo praktiskās dzīves aspektu. Proti, LTV paustā nācijas koncepcija ir reducēta uz J. Hābermasa kultūras publisko sfēru, kuras mērḳis ir latviešu etniskās un profesionālās kultūras saglabāšana, taču ne ikdienas "egoistiskās" ekonomiskās un sociālās dzīves aspektu apspriešana.

Latvijas iedzīvotājus kritizē par nespēju paskatīties pāri savai sētai. Faktiski no J. Juzefoviča informantu sacītā var secināt: viņus neapmierina tas, ka viņiem piedāvā tikai kultūras publisko sfēru, atstājot novārtā politisko, kurā viņi varētu runāt par savām "savtīgām" atšķirībām, meklējot kopību ar citiem.

\title{
PĒTĪJUMĀ MEKLĒTAS ATBILDES
}

\author{
Guntis Zemītis, Dr. hist., Biznesa augstskolas Turība profesors, \\ LU Latvijas vēstures institūta direktors
}

Objektīvas recenzijas ir anonīmas. Publicēta recenzija vienlaicīgi kḷūst par recenzenta publikāciju. Tāpēc publicētā recenzijā gribot negribot mēdz izpausties recenzenta subjektīvisms, aiz kura reizēm pazūd pats recenzijas objekts. Šì recenzija noteikti nevar pretendēt uz pilnīgu objektivitāti - Andris Pētersons ir recenzentam labi pazīstams, recenzents rakstījis šīs viṇa monogrāfijas ([2017] Latvijas iedzīvotāju atvērtība starpkultūru komunikācijai. Rīga : Biznesa augstskola Turība) priekšvārdu un pat minēts kā tās konsultants. Un tomēr - monogrāfija neapšaubāmi ir A. Pētersona autora darbs. Viņš vienīgais ir interpretējis pētījuma rezultātus un pasniedz tos savā monogrāfijā. Tas, ka recenzents ir pazīstams ar A. Pētersona agrākajiem darbiem, viṇa rakstīšanas stilu, pat darba stilu un domāšanas veidu, ne tikai netraucē, bet arī palīdz labāk izprast viņa ieceres, materiālu atlases veidu un secinājumu būtību.

Pētījums, kuru veica Biznesa augstskolas Turība studenti A. Pētersona vadībā par Latvijas iedzīvotāju (domāti visi pastāvīgie 